\title{
Herlyn-Werner-Wunderlich syndrome (uterus didelphys, blind hemivagina and ipsilateral renal agenesis) - a case report
}

\author{
Herlyn-Werner-Wunderlich Sendromu (uterus didelphys, kör hemivajen ve ipsilateral \\ renal agenezi) - vaka sunumu
}

\author{
İlker İnan Arıkan, Müge Harma, Mehmet İbrahim Harma, Ülkü Bayar, Aykut Barut \\ Department of Obstetrics and Gynecology, Zonguldak Karaelmas University Faculty of Medicine, Zonguldak, Turkey
}

\section{Abstract}

Uterovaginal duplication with obstructed hemivagina and ipsilateral renal agenesis is referred to as the Herlyn-Werner-Wunderlich (HWW) syndrome. A 17 year old woman presented with right pelvic pain and dysmenorrhea, present since menarche at 13 and worsening over the past year. Ultrasound examination revealed a right pelvic mass $(5 \times 5 \mathrm{~cm})$, double endometrial echoes, and hematocolpos. A right pelvic mass, agenesis of the right kidney, double uterus, and blind hemivagina with hematocolpos were detected by magnetic resonance imaging and intravenous pyelography. A right tubo-ovarian abscess with dense adhesions and a double uterus were observed on diagnostic laparoscopy. Adhesiolysis was carried out and purulent material irrigated. After a course of antibiotics, a vaginal septum resection was performed and the pyocolpos drained. She remained symptom free after four months of follow-up. Prompt and accurate diagnosis and treatment of this syndrome can significantly improve the lives of sufferers and prevent future complications.

(J Turkish-German Gynecol Assoc 2010; 11: 107-9)

Key words: Blind hemivagina, Herlyn-Werner-Wunderlich syndrome, Müllerian duct anomaly, Pyocolpos, Uterus didelphys

Received: 13 November, 2009

Accepted: 16 December, 2009

\section{Özet}

Kör hemivajen ile beraber olan uterovajinal duplikasyon ve ipsilateral renal agenezi Herlyn-Werner-Wunderlich (HWW) Sendromu olarak tanımlanır. 17 yaşındaki hasta; 13 yaşında gördüğü ilk adetinden itibaren olan ve son bir yılda şiddeti artan sağ kasık ağnısı ve dismenore şikayetleri ile acil servise başvurdu. Ultrasonda; sağ pelvik kitle $(5 \times 5 \mathrm{~cm})$, çifte endometrial eko ve hematokolpos tespit edildi. Yapılan magnetik rezonans görüntülemesi ve intravenöz pyelografisinde; sağ pelvik kitle, sağ böbrek agenezi, çifte uterus, ve hematokolposla beraber olan kör hemivajen tespit edildi. Yapılan diagnostik laparoskopide; kalın yapışıklıklarla olan sağ tubaovaryen abse ve çift uterus tespit edildi. Abse drene edildi ve yapışıklıklar açıldı. Hastaya antibiyotik tedavisi verildikten sonra tekrar opere edildi ve vajinal septum eksize edilerek pyokolpos drene edildi. Hastanın takiplerinde herhangi bir şikayeti olmadı. Bu sendromun erken ve doğru tespit ve tedavisi, bu problemi yaşayan hastaların refahını belirgin olarak artırabilir ve yaşanabilecek komplikasyonları engelleyebilir.

(J Turkish-German Gynecol Assoc 2010; 11: 107-9)

Anahtar kelimeler: Kör hemivajen, Herlyn-Werner-Wunderlich sendromu, Müllerian kanal anomalisi, Pyokolpos, Uterin didelfus

Geliş Tarihi: 13 Kasım 2009

Kabul Tarihi: 16 Aralık 2009

of this embryological event, different types of uterine anomalies can arise, such as agenesis, hypoplasia, unicornuate, didelphys, bicornuate, arcuate, and septate uterus (3). The American Society of Reproductive Medicine has classified these malformations under seven groups (5), while Acien et al have more recently proposed a clinical embryological classification of all genital tract malformations (1).

Finally, the lower third of the vagina develops from the joining of the Mullerian ducts and the urogenital sinus (6). Vaginal anomalies, such as aplasia, hypoplasia, septa or duplication, may exist alone or accompany the Mullerian anomalies, due to the different embryological origins (3).

Uterovaginal duplication with obstructed hemivagina and ipsilateral renal agenesis is referred to as the Herlyn-WernerWunderlich (HWW) syndrome (3). Embryological arrest at 8 weeks of gestation is the cause of uterine didelphys with 
renal agenesis, and in the general population the reported incidence for this anomaly is $0.1-3.8 \%(2,7)$. A complete vaginal septum is present in $75 \%$ of women with uterine didelphys (8). Most of the patients present at menarche with symptoms of pelvic pain secondary to hematocolpos, fever, and abcess formation (2). Unfortunately, making the diagnosis of HWW syndrome is not always simple. The experience with HWW syndrome was definitely limited, consisting of case reports. Resection of the vaginal septum mostly relieves the pain and prevents further complications. In this case report, we wish to emphasize the need for early and accurate diagnosis for the correct treatment of this entity.

\section{Case History}

A 17-year-old woman presented to the Emergency Unit with complaints of right pelvic pain and dysmenorrhea. The symptoms had become more intense over the past year, and she had used non-steroidal anti-inflammatory drugs (NSAIDs) prescribed by her primary care physician for the last six months, but her condition had not improved. She had experienced menarche when she was 13 years old and had a history of regular menses with cyclic pelvic pain.

Tenderness in the right lower abdomen, and normal vulva, anus and hymen were noted at her first clinical examination. Her ultrasound examination revealed a right pelvic mass $(5 \times 5 \mathrm{~cm})$, double endometrial echoes, and hematocolpos. Because she was a virgin, traditional issues prevented a vaginal examination. A right pelvic mass, agenesis of the right kidney, double uterus, and blind hemivagina with hematocolpos were detected by magnetic resonance imaging (MRI) (Figure 1) and intravenous pyelography (IVP) (Figure 2).

Diagnostic laparoscopy was performed, and a right tuba-ovarian abscess with dense adhesions and a double uterus were observed. Adhesiolysis was carried out and purulent material irrigated. The patient was treated with oflaxacin $400 \mathrm{mg} / \mathrm{day}+$ metronidazole $1.5 \mathrm{~g} /$ day for 14 days in preparation for operation. After we received the informed consent of the patient, we performed a vaginal septum resection and detected a pyocolpos, which was drained. Both cervixes were also explored.

After the operation, her pain improved and she was discharged from the hospital on the $11^{\text {th }}$ post-operative day. Her follow up was symptom-free at the $4^{\text {th }}$ postoperative month.

\section{Discussion}

The exact etiology and pathogenesis of HWW syndrome are still not known $(3,9,10)$, but are probably related to the fact that the Wolffian ducts play an important role in the precise development of internal genital organs as well as giving rise to the kidneys $(3,4,9)$. They are inductor elements for adequate Mullerian ducts fusion. For this reason, embryologic anomaly of one Wolffian ducts may cause unilateral renal agenesis associated with imperforate hemivagina $(4,11)$. This hypothesis is supported by Gruenwald's experiment in chick embryos,

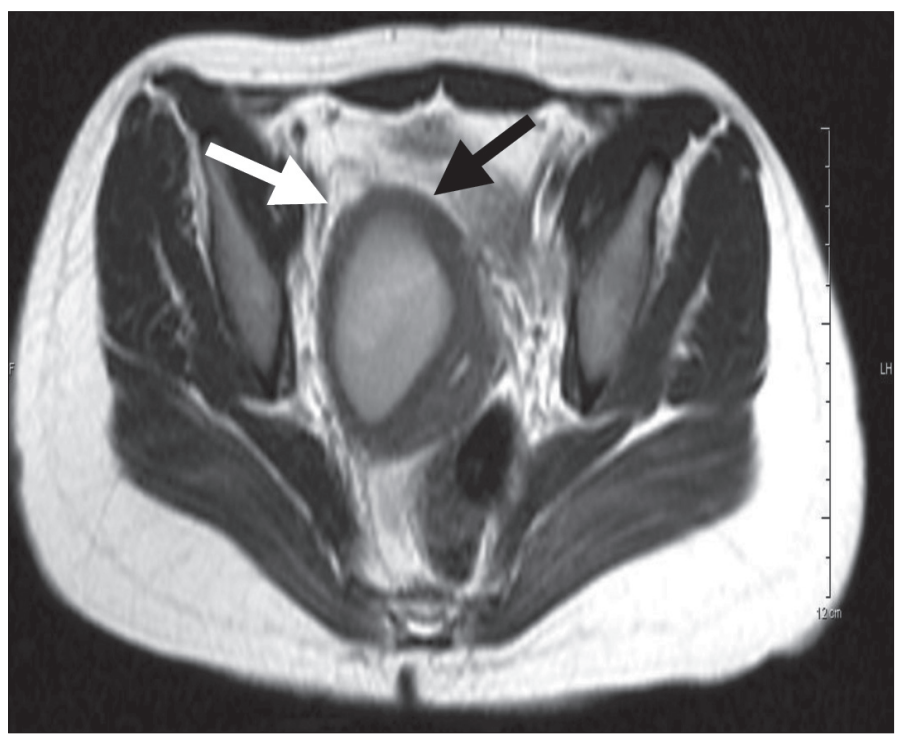

Figure 1. Right hemivagina with pyocolpos

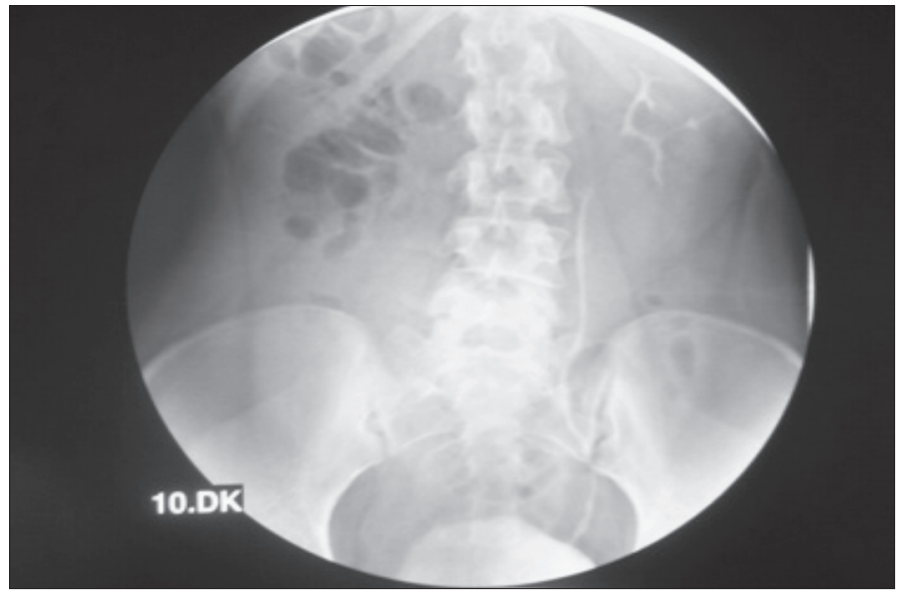

Figure 2. Intravenous pyelography, absent right kidney

where ipsilateral renal and Mullerian duct anomalies were produced following the destruction of the caudal portion of the mesonephros (12). On the affected side, Mullerian ducts cannot fuse, resulting in a didelphic uterus, and cannot come into contact with the urogenital sinus centrally, forming two separate vaginas with one obstructed (3).

The syndrome usually presents with progressive and recurrent pelvic pain after the menarche. It is not initially diagnosed, because of the regular menstrual flow from the unobstructed vagina. Some time after menarche, the retention of menstrual blood in the obstructed hemivagina leads to the formation of a haematocolpos, which is usually clinically detected as a pelvic mass. A right sided prevalence of the obstructed system has been mentioned in the literature $(7,12,13)$. Diagnosis may be further delayed if a communication between the two vaginas exists (3). Not only a dilated hemivagina but also a dilated uterine cavity and fallopian tube may be present at the time of diagnosis. Especially in delayed cases, bleeding into the peritoneal space may occur as a consequence of retrograde menstruation. Endometriosis can also be formed in these patients $(7,8,13)$. 
Ultrasonography and MRI are widely and effectively used in the diagnosis of genitourinary anomalies, with even 100\% accuracy being reported for MRI because of its high accuracy and detailed elaboration of uterovaginal anatomy $(14,15)$. However, since 1981 laparoscopic exploration has been regarded as the gold standard $(2,7)$.

Renal malformations are now usually detected at the perinatal period and in the case of a renal agenesis or multicystic dysplastic kidney, detected in female newborn. The Mullerian system should also be checked for a malformation (16).

It is the least common but has the best prognosis of Mullerian duct anomalies (17). The definitive treatment of HWW syndrome is the resection of as much of the obstructing vaginal septum as possible. This rapidly relieves the symptoms and prevents complications related to chronic cryptomenorrhae, such as endometriosis, pelvic adhesions, and infectious collections $(2,3,10,13)$. Candiani et al. have suggested marsupializing the vaginal margins after excision of the septum to allow ample drainage of the purulent material and better expose the cervix (7). Fertility is preserved with this surgery, which is not significantly decreased in women with a didelphic uterus (3).

\section{Conclusion}

The prompt and accurate diagnosis of female reproductive tract disorders, including HWW syndrome, is necessary to prevent complications and preserve future fertility. The cooperation of pediatricians, pediatric surgeons, radiologists, and gynecologists is essential to avoid complications due to diagnostic delay. In conclusion, early recognition of this relatively rare syndrome would lead to the immediate, proper surgical intervention. Laparoscopy provided additional information beyond radiologic tests regarding pelvic anatomy. This approach should retrieve affected cases, which would otherwise face a rather discouraging future.

\section{Conflict of interest}

None declared

\section{References}

1. Acién P, Acién M, Sánchez-Ferrer M. Complex malformations of the female genital tract. New types and revision of classification. Hum Reprod 2004; 19: 2377-84
2. Zurawin RK, Dietrich JE, Heard MJ, Edwards CL. Didelphic uterus and obstructed hemivagina with renal agenesis: case report and review of the literature. J Pediatr Adolesc Gynecol 2004; 17: 137-41.

3. Orazi C, Lucchetti MC, Schingo PM, Marchetti P, Ferro F. HerlynWerner-Wunderlich syndrome: uterus didelphys, blind hemivagina and ipsilateral renal agenesis. Sonographic and MR findings in 11 cases. Pediatr Radiol 2007; 37: 657-65.

4. Acien P. Embrological observations on the female genital tract. Hum Reprod 1992; 7: 437-45.

5. American Fertility Society. The American Fertility Society classifications of adnexal adhesions, distal tubal occlusion, tubal occlusion secondary to tubal ligation, tubal pregnancies. Mullerian duct anomalies and intrauterine adhesions. Fertil Steril 1988; 49: 944-55.

6. Sadlar TW, Langman J (eds). Langman's Medical Embryology, 8th edn. Philadelphia: Lippincott Williams and Wilkins, 2000.

7. Burgis J. Obstructive Mullerian anomalies: Case report, diagnosis, and management. Am J Obstet Gynecol 2001; 185: 338-44.

8. Heinonen PK. Clinical implications of the didelphic uterus: longterm follow-up of 49 cases. Eur J Obstet Gynecol Reprod Biol 2000; 91: 183-90.

9. Candiani GB, Fedele L, Candiani M. Double uterus, blind hemivagina and ipsilateral renal agenesis: 36 cases and long-term follow-up. Obstet Gynecol 1997; 90: 26-32.

10. Haddad B, Barranger E, Paniel BJ. Blind hemivagina: long-term follow-up and reproductive performance in 42 cases. Hum Reprod 1999; 14: 1962-4.

11. Stassart JP, Nagel TC, Prem KA, Phipps WR. Uterus didelphys, obstructed hemivagina, and ipsilateral renal agenesis: the University of Minnesota experience. Fertil Steril. 1992; 57: 756-61.

12. Gruenwald P. Relation of the growing mullerian duct to the wolffian duct and its importance for the genesis of malformation. Anat Rec 1941; 81: 1-20.

13. Gholoum S, Puligandla PS, Hui T, Su W, Quiros E, Laberge JM. Management and outcome of patients with combined vaginal septum, bifid uterus and ipsilateral renal agenesis (Herlyn-Werner-Wunderlich syndrome). J Pediatr Surg 2006; 41: 987-92.

14. Marten K, Vosshenrich R, Funke M, Obenauer S, Baum F, Grabbe E. MRI in the evaluation of mullerian anomalies. Clin Imaging 2003; 16: 337-47.

15. Troiano RN, McCarthy SM. Mullerian duct anomalies: imaging and clinical issues. Radiology. 2004; 233: 19-34.

16. Prada Arias M, Muguerza Vellibre R, Montero Sánchez M, Vázquez Castelo JL, Arias González M, Rodríguez Costa A. Uterus didelphys with obstructed hemivagina and multicystic dysplastic kidney. Eur J Pediatr Surg. 2005 Dec; 15: 441-5.

17. Hoeffel C, Olivier M, Scheffler C, Chelle C, Hoeffel JC. Uterus didelphys, obstructed hemivagina and ipsilateral renal agenesis. Eur J Radiol. 1997; 25: 246-8. 